\title{
TWENTY-SIXTH ANNUAL LIST OF PAPERS
}

READ BEFORE THE AMERICAN MATHEMATICAL SOCIETY AND SUBSEQUENTLY PUBLISHED, INCLUDING REFERENCES

TO THE PLACES OF THEIR PUBLICATION.

Alexander, J. W., II. On the factorization of Cremona plane transformations. Read Dec. 28, 1915. Transactions of the American Mathematical Society, vol. 17, No. 3, pp. 295-300; July, 1916.

Bateman, $H$. On systems of partial differential equations and the transformation of spherical harmonics. Read Feb. 26, 1916. Proceedings of the Royal Society of Edinburgh, vol. 36, Nos. 3-4, pp. 300-312; March, 1917.

Beal, F. W. A congruence of circles. Read April 24, 1915. Annals of Mathematics, ser. 2, vol. 17, No. 4, pp. 180-187; June, 1916.

Beatту, S. The inversion of an analytic function. Read April 28, 1917. Bulletin of the American Mathematical Society, vol. 23, No. 8, pp. 347353; May, 1917.

Bennetr, A. A. A case of iteration in several variables. Read April 29, 1916. Annals of Mathematics, ser. 2, vol. 17, No. 4, pp. 188-196; June, 1916.

- An existence theorem for the solution of a type of real mixed difference equation. Read April 29, 1916. Annals of Mathematics, ser. 2, vol. 18, No. 1, pp. 24-30; Sept., 1916.

— Newton's method in general analysis. Read (Southwestern Section) Dec. 2, 1916. Proceedings of the National Academy of Sciences, vol. 2, No. 10, pp. 592-598; Oct., 1916.

- Closed algebraic correspondences. Read (Chicago) Dec. 22, 1916. Annals of Mathematics, ser. 2, vol. 18, No. 4, pp. 200-208; June, 1917.

BIRкноFF, G. D. Infinite products of analytic matrices. Read Dec. 27, 1915. Transactions of the American Mathematical Society, vol. 17, No. 3, pp. 386-404; July, 1916.

- Dynamical systems with two degrees of freedom. Read Dec. 27, 1915 and Sept. 5, 1916. Proceedings of the National Academy of Sciences, vol. 3, No. 4, pp. 314-316; April, 1917. Transactions of the American Mathematical Society, vol. 18, No. 2, pp. 199-300; April, 1917.

Blumberg, H. On the factorization of expressions of various types. Read (Southwestern Section) Nov. 28, 1914 and (Chicago) Dec. 29, 1914. Transactions of the American Mathematical Society, vol. 17, No.4, pp. 517-544; Oct., 1916.

- Certain general properties of functions. Read (Chicago) April 10, 1914 and (Chicago) Dec. 22, 1916. Proceedings of the National Academy of Sciences, vol. 2, No. 11, pp. 646-649; Nov., 1916. Annals of Mathematics, ser. 2, vol. 18, No. 3, pp. 147-160; March, 1917.

Bôcher, M. La méthode des approximations successives pour les systèmes différentiels. Read Sept. 8, 1914. Section 22, pp. 112-116, of Leçons sur les Méthodes de Sturm dans la Théorie des Equations différentielles linéaires et leurs Développements modernes. (Collection de Monographies sur la Théorie des Fonctions publiée sous la Direction de M. Emile Borel.) Paris, Gauthier-Villars, 1917. 
Borger, R. L. A theorem in the analysis of real variables. Read (Chicago) April 21, 1916. Bulletin of the American Mathematical Society, vol. 23, No. 6, pp. 287-290; March, 1917.

Brown, E. W. The relations of mathematics to the natural sciences. Read Dec. 28, 1916. Bulletin of the American Mathematical Society, vol. 23, No. 5, pp. 213-230; Feb., 1917.

Buchanan, D. Oscillations near an isosceles-triangle solution as the finite bodies become unequal. Read (Chicago) Dec. 28, 1914. American Journal of Mathematics, vol. 39, No. 1, pp. 41-58; Jan., 1917.

Burgess, H. T. A practical method for determining elementary divisors. Read (Chicago) April 21, 1916. Annals of Mathematics, ser. 2, vol. 18, No. 1, pp. 4-6; Sept., 1916.

Burgess, R. W. The comparison of a certain case of the elastic curve with its approximation. Read Sept. 4, 1916. Physical Review, ser. 2, vol. 9, No. 3, pp. 193-197; March, 1917.

Carmichael, R. D. On a general class of series of the form $\Sigma c_{n} g(x+n)$. Read Dec. 31, 1915. Transactions of the American Mathematical Society, vol. 17, No. 3, pp. 207-232; July, 1916.

Examples of a remarkable class of series. Read April 28, 1917. Bulletin of the American Mathematical Society, vol. 23, No. 9, pp. 407425; June, 1917.

Carpenter, A. F. Ruled surfaces whose flecnode curves have plane branches. Read (San Francisco) May 22, 1914, (Chicago) Dec. 28, 1914, and (Chicago) April 2, 1915. Transactions of the American Mathematical Society, vol. 16, No. 4, pp. 509-532; Oct., 1915.

Carslaw, H. S. A trigonometrical sum and the Gibbs' phenomenon in Fourier's series. Read Oct. 30, 1915. American Journal of Mathematics, vol. 39, No. 2, pp. 185-197; April, 1917.

Chittenden, E. W. On the equivalence of écart and voisinage. Read (Chicago) April 21, 1916. Transactions of the American Mathematical Society, vol. 18, No. 2, pp. 161-166; April, 1917.

Coble, A. B. Point sets and allied Cremona groups (Part II). Read April 25, 1914. Transactions of the American Mathematical Society, vol. 17, No. 3, pp. 345-385; July, 1916.

- Point sets and Cremona groups. Part III. Read April 25, 1914. Proceedings of the National Academy of Sciences, vol. 2, No. 10, pp. 575576; Oct., 1916.

Cole, F. N., Cummings, L. D., and White, H. S. The complete enumeration of triad systems in 15 elements. Read Sept. 8, 1914, Oct. 31, 1914, Aug. 4, 1915, and Oct. 28, 1916. Proceedings of the National Academy of Sciences, vol. 3, No. 3, pp. 197-199; March, 1917.

Coolidge, J. L. The meaning of Plücker's equations for a real curve. Read Dec. 28, 1915 and April 29, 1916. Rendiconti del Circolo Matematico di Palermo, vol. 40, Nos. 2-3, pp. 211-216; Sept.-Dec., 1915.

The intersections of a straight line and hyperquadric. Read Dec. 28, 1916. Annals of Mathematics, ser. 2, vol. 18, No. 4, pp. 209-213; June, 1917.

Cummings, L. D. See Cole, F. N.

Dantzig, T. Démonstration directe du dernier théorème de Henri Poincaré. Read (Chicago) April 22, 1916. Bulletin des Sciences Mathématiques, ser. 2, vol. 41, No. 2, pp. 53-58; Feb., 1917. 
Dickson, L. E. An extension of the theory of numbers by means of correspondences between fields. Read Sept. 4, 1916. Bulletin of the American Mathematical Society, vol. 23, No. 3, pp. 109-111; Dec., 1916.

Dines, C. R., Functions of positive type and related topics in general analysis. Read (Chicago) April 3, 1915. Proceedings of the London Mathematical Society, ser. 2, vol. 15, No. 4, pp. 243-279; Aug., 1916.

Dines, L. L. A characteristic property of self-projective curves. Read (Chicago) April 21, 1916. Annals of Mathematics, ser. 2, vol. 17, No. 4, pp. 213-217; June, 1916.

Dresden, A. On the second derivatives of the extremal-integral with an application to a problem with variable end points. Read (Chicago) Dec. 28, 1914. Transactions of the American Mathematical Society, vol. 17, No. 4, pp. 425-436; Oct., 1916.

Eisenhart, L. P. Sulle superficie di rotolamento e le trasformazioni di Ribaucour. Read Aug. 4, 1915. Accademia dei Lincei, Rendiconti, vol. 24, 2d sem., No. 8, pp. 349-352; Nov. 5, 1915.

- Surfaces generated by the motion of an invariable curve whose points describe straight lines. Read Dec. 28, 1915. Rendiconti del Circolo Matematico di Palermo, vol. 41, No. 1, pp. 94-102; Jan.-April, 1916.

— Conjugate systems with equal point invariants. Read April 29, 1916. Annals of Mathematics, ser. 2, vol. 18, No. 1, pp. 7-17; Sept., 1916.

- Deformable transformations of Ribaucour. Read Sept. 4, 1916. Transactions of the American Mathematical Society, vol. 17, No. 4, pp. 437-458; Oct., 1916.

- Transformations $T$ of conjugate systems of curves on a surface. Read Dec. 27, 1916. Transactions of the American Mathematical Society, vol. 18, No. 1, pp. 97-124; Jan., 1917.

- Conjugate planar nets with equal invariants. Read April 28, 1917. Annals of Mathmatics, ser. 2, vol. 18, No. 4, pp. 221-225; June, 1917.

Elmendorf, A. A differentiating machine. Read (Chicago) April 22, 1916. American Mathematical Monthly, vol. 23, No. 8, pp. 292-295; Oct., 1916.

EмcH, A. An application of a group of order 16 to a configuration on an elliptic cubic. Read (Chicago) April 21, 1916. Annals of Mathematics, ser. 2, vol. 18, No. 1, pp. 45-52; Sept., 1916.

- A theorem on the curves described by a spherical pendulum. Read Dec. 27, 1916. Bulletin of the American Mathematical Society, vol. 23, No. 5, pp. 230-232; Feb., 1917.

Fine, H. B. On Newton's method of approximation. Read April 29, 1916. Proceedings of the National Academy of Sciences, vol. 2, No. 9, pp. 546-552; Sept., 1916.

Fischer, C. A. Functions of surfaces with exceptional points or curves. Read Aug. 3, 1915. American Journal of Mathematics, vol. 38, No. 3, pp. 259-266; July, 1916.

- Note on the order of continuity of functions of lines. Read Sept. 4, 1916. Bulletin of the American Mathematical Society, vol. 23, No. 2, pp. 88-90; Nov., 1916.

- Equations involving the partial derivatives of a function of a surface. Read Feb. 26, 1916. American Journal of Mathematics, vol. 39, No. 2, pp. 123-134; April, 1917. 
Fite, W. B. The relation between the zeros of a solution of a linear bomogeneous differential equation and those of its derivatives. Read Oct. 30, 1915. Annals of Mathematics, ser. 2, vol. 18, No. 4, pp. 214220; June, 1917.

Ford, W. B. On the representation of arbitrary functions by definite integrals. Read (Chicago) April 3, 1915. American Journal of Mathematics, vol. 38, No. 4, pp. 397-406; Oct., 1916.

Forsyth, C. H. Interpolation of ordinates and areas among areas. Read (Southwestern Section) Nov. 27, 1915. Quarterly Publications of the American Statistical Association, new ser., vol. 15, No. 116, pp. 418425; Dec., 1916.

FonT, T. Linear difference and differential equations. Read Dec. 27, 1915. American Journal of Mathematics, vol. 39, No. 1, pp. 1-26; Jan., 1917.

Glens, O. E. On the invariant system of a pair of connexes. Read Feb. 27, 1915 and Feb. 26, 1916. Transactions of the American Mathematical Society, vol. 17, No. 4, pp. 405-417; Oct., 1916.

- The formal modular invariant theory of binary quantics. Read Feb. 26, 1916. Transactions of the American Mathematical Society, vol. 17, No. 4, pp. 545-556; Oct., 1916.

Translation surfaces associated with line congruences. Read Oct. 28, 1916. Bulletin of the American Mathematical Society, vol. 23, No. 3, pp. 122-127; Dec., 1916.

Graustein, W. C. On the geodesics and geodesic circles on a developable surface. Read Jan. 2, 1915. Annals of Mathematics, ser. 2, vol. 18, No. 3, pp. 132-138; March, 1917.

Green, G. M. Projective differential geometry of one-parameter families of space curves, and conjugate nets on a curved surface. Second memoir. Read Feb. 28, 1914 and Oct. 30, 1915. American Journal of Mathematics, vol. 38, No. 3, pp. 287-324; July, 1916.

The linear dependence of functions of several variables, and completely integrable systems of homogeneous linear partial differential equations. Read Oct. 31, 1914 and Oct. 30, 1915. Transactions of the American Mathematical Society, vol. 17, No. 4, pp. 483-516; Oct., 1916.

On the linear dependence of functions of one variable. Read Sept. 5, 1916. Bulletin of the American Mathematical Society, vol. 23, No. 3, pp. 118-122; Dec., 1916.

Gronwall, T. H. Sur la déformation dans la représentation conforme. Read Jan. 2, 1915 and Feb. 26, 1916. Comptes Rendus de l'Académie des Sciences, vol. 162, No. 7, pp. 249-252; Feb. 14, 1916.

- Sur la déformation dans la représentation conforme sous des conditions restrictives. Read Jan. 2, 1915 and Feb. 26, 1916. Comptes Rendus de l'A cadémie des Sciences, vol. 162, No. 9, pp. 316-318; Feb. 28, 1916.

- Ueber einige Summationsmethoden und ihre Anwendung auf Fouriersche Reihe. Read (Chicago) March 21, 1913. Journal für die reine und angewandte Mathematik, vol. 147, No. 1, pp. 16-35; July, 1916.

- A problem in geometry connected with the analytic continuation of a power series. Read Sept. 5, 1916. Annals of Mathematics, ser. 2, vol. 18, No. 2, pp. 65-69; Dec., 1916. 
On the power series for $\log (1+z)$. Read Sept. 5, 1916. Annals of Mathematics, ser. 2, vol. 18, No. 2, pp. 70-73; Dec., 1916.

On the convergence of Binet's factorial series for $\log \Gamma(s)$ and $\psi(s)$. Read Sept. 5, 1916. Annals of Mathematics, ser. 2, vol. 18, No. 2, pp. 74-78; Dec., 1916.

- On the expressibility of a uniform function of several complex variables as the quotient of two functions of entire character. Read Oct. 25, 1913. Transactions of the American Mathematical Society, vol. 18, No. 1, pp. 50-64; Jan., 1917.

HARDING, A. M. On certain loci projectively connected with a given plane curve. Read (Chicago) April 22, 1916. Giornale di Matematiche, vol. 54, Nos. 3-5, pp. 185-222; May-Oct., 1916.

HARDY, G. H. Weierstrass's non-differentiable function. Read (Southwestern Section) Nov. 27, 1915. Transactions of the American Mathematical Society, vol. 17, No. 3, pp. 301-325; July, 1916.

Hart, W. L. On trigonometric series. Read (Chicago) April 10, 1914. Annals of Mathematics, ser. 2, vol. 18, No. 2, pp. 99-104; Dec., 1916.

—Differential equations and implicit functions in infinitely many variables. Read (Chicago) April 2, 1915 and Jan. 1, 1916. Proceedings of the National Academy of Sciences, vol. 2, No. 6, pp. 309-313; June, 1916. Transactions of the American Mathematical Society, vol. 18, No. 2, pp. 125-160; April, 1917.

HASKelL, M. W. The maximum number of cusps of an algebraic plane curve, and enumeration of self-dual curves. Read (San Francisco) Oct. 24, 1914. Bulletin of the American Mathematical Society, vol. 23, No. 4, pp. 164-165; Jan., 1917.

HAssLer, J. O. Plane nets periodic of period 3 under the Laplacian transformation. Read (Chicago) April 22, 1916. Rendiconti del Circolo Matematico di Palermo, vol. 40, Nos. 2-3, pp. 273-294; Sept.-Dec., 1915.

HAzLETt, O. C. On the rational, integral invariants of nilpotent algebras. Read Dec. 27, 1915. Annals of Mathematics, ser. 2, vol. 18, No. 2, pp. 81-98; Dec., 1916.

- On the theory of associative division algebras. Read Sept. 4, 1916. Transactions of the American Mathematical Society, vol. 18, No. 2, pp. 167-176; April, 1917.

Hedrick, E. R. and Westfall, W. D. A. Sur l'existence des fonctions implicites. Read Sept. 8, 1913 and (Southwestern Section) Nov. 29, 1913. Bulletin de la Société Mathématique de France, vol. 44, No. 1, pp. 1-13; Oct., 1916.

Hewes, L. I. Nomograms of adjustment. Read Sept. 5, 1916. Annals of Mathematics, ser. 2, vol. 18, No. 4, pp. 194-199; June, 1917.

HiLDEBRANDT, T. H. On a theory of linear differential equations in general analysis. Read Dec. 31, 1915. Transactions of the American Mathematical Society, vol. 18, No. 1, pp. 73-96; Jan., 1917.

Huntington, E. V. A set of independent postulates for cyclic order. Read Dec. 27, 1916. Proceedings of the National Academy of Sciences, vol. 2, No. 11, pp. 630-631; Nov., 1916.

- Complete existential theory of the postulates for serial order. Read Dec. 27, 1916. Bulletin of the American Mathematical Society, vol. 23, No. 6, pp. 276-280; March, 1917. 
Complete existential theory of the postulates for well ordered sets. Read Dec. 27, 1916. Bulletin of the American Mathematical Society, vol. 23, No. 6, pp. 280-282; March, 1917.

Hurwitz, W. A. and Silverman, L. L. On the consistency and equivalence of certain definitions of summability. Read Sept. 8, 1914. Transactions of the American Mathematical Society, vol. 18, No. 1, pp. 1-20; Jan., 1917.

JACKson, D. Non-essential singularities of functions of several complex variables. Read Oct. 30, 1915. Annals of Mathematics, ser. 2, vol. 17, No. 4, pp. 172-179; June, 1916.

- Algebraic properties of self-adjoint systems. Read Dec. 27, 1915. Transactions of the American Mathematical Society, vol. 17, No. 4, pp. 418-424; Oct., 1916.

- Note on representations of the partial sum of a Fourier's series. Read Sept. 4, 1916. Annals of Mathematics, ser. 2, vol. 18, No. 3, pp. 139-146; March, 1917.

JofFe, S. A. Calculation of the first thirty-two Eulerian numbers from central differences of zero. Read Feb. 26, 1916. Quarterly Journal of Pure and Applied Mathematics, vol. 47, No. 2, pp. 103-126; July, 1916.

KAsNer, E. Equilong invariants and convergence proofs. Read April 24, 1915. Bulletin of the American Mathematical Society, vol. 23, No. 8, pp. 341-347; May, 1917.

KEMPNER, A. J. On transcendental numbers. Read Dec. 31, 1915. Transactions of the American Mathematical Society, vol. 17, No. 4, pp. 476-482; Oct., 1916.

Kingston, H. R. Metric properties of nets of plane curves. Read Sept. 9, 1914 and (Chicago) Dec. 29, 1914. American Journal of Mathematics, vol. 38 , No. 4, pp. 407-430; Oct., 1916.

KLINE, J. R. Double elliptic geometry in terms of point and order alone. Read April 24, 1915. Annals of Mathematics, ser. 2, vol. 18, No. 1, pp. 31-44; Sept., 1916.

- Concerning the complement of a countable infinity of point sets of a certain type. Read Dec. 27, 1916. Bulletin of the American Mathematical Society, vol. 23, No. 6, pp. 290-292; March, 1917.

- The converse of the theorem concerning the division of a plane by an open curve. Read Oct. 28, 1916. Transactions of the American Mathematical Society, vol. 18, No. 2, pp. 177-184; April, 1917.

KüstermanN, W. W. Funktionen von beschränkter Schwankung in zwei reellen Veränderlichen. Read Dec.31, 1915. Mathematische Annalen, vol. 77, No. 4, pp. 474-481; Sept., 1916.

- Fourier's constants of functions of several variables. Read Aug. 3, 1915. American Journal of Mathematics, vol. 39, No. 2, pp. 113-122; April, 1917.

LEFSCHETZ, S. On the residues of double integrals belonging to an algebraic surface. Read (Southwestern Section) Dec. 2, 1916. Quarterly Journal of Pure and Applied Mathematics, vol. 47, No. 4, pp. 333-343; Jan., 1917.

Sur certains cycles à deux dimensions des surfaces algébriques. Read (Chicago) April 7, 1917. Accademia dei Dincei, Rendiconti, vol. 26, 1st sem., No. 4, pp. 228-234; Feb. 18, 1917. 
Leuschner, A. O. The derivation of orbits, theory and practise. Read Dec. 28 , 1916. Science, new ser., vol. 45 , No. 1171, pp. 571-584; June 8, 1917.

LigHT, G. H. The dependence of the topography of envelopes of systems of extremals on curvature. Read (Southwestern Section) Dec. 2, 1916. Author's dissertation. Lancaster, 1917. $32 \mathrm{pp}$.

LipкA, J. Natural and isogonal families of curves on a surface. Read Dec. 28, 1915. Proceedings of the National Academy of Sciences, vol. 3, No. 2, pp. 78-83; Feb., 1917.

Longley, W. R. Note on a theorem on envelopes. Read Oct. 30, 1915. Annals of Mathematics, ser. 2, vol. 17, No. 4, pp. 169-171; June, 1916.

Lovitr, W. V. Some singularities of a contact transformation. Read (Chicago) April 2, 1915. American Journal of Mathematics, vol. 39, No. 1, pp. 27-40; Jan., 1917.

McMackin, F. J. Some theorems in the theory of summable divergent series. Read April 29, 1916. Author's dissertation. Lancaster, 1916. $23 \mathrm{pp}$.

MaCMillan, W. D. A reduction of certain analytic differential equations to differential equations of an algebraic type. Read (Chicago) Dec. 26, 1913 and (Chicago) April 11, 1914. Transactions of the American Mathematical Society, vol. 17, No. 3, pp. 245-258; July, 1916.

- A theorem connected with irrational numbers. Read (Chicago) April 21, 1916. Proceedings of the National Academy of Sciences, vol. 1, No. 7, pp. 437-438; July, 1915. American Journal of Mathematics, vol. 38, No. 4, pp. 387-396; Oct., 1916.

Miller, B. I. A new canonical form of the elliptic integral. Read Dec. 27, 1915. Transactions of the American Mathematical Society, vol. 17, No. 3, pp. 259-283; July, 1916.

Miller, G. A. Finite groups represented by special matrices. Read Jan. 1, 1916. Transactions of the American Mathematical Society, vol. 17, No. 3, pp. 326-332; July, 1916.

- Graphical method of finding the possible sets of independent generators of an abelian group. Read (Chicago) April 22, 1916. Bulletin of the American Mathematical Society, vol. 23, No. 1, pp. 14-17; Oct., 1916.

- Orders of operators of congruence groups modulo $2^{r} 3^{s}$. Read Sept. 4, 1916. Messenger of Mathematics, vol. 46, No. 7, pp. 101-103; Nov., 1916.

- Groups generated by two operatörs of the same prime order such that the conjugates of one under the powers of the other are commutative. Read Dec. 28, 1916. Bulletin of the American Mathematical Society, vol. 23, No. 6, pp. 283-287; March, 1917.

Milne, W. E. Note on asymptotic expressions in the theory of linear differential equations. Read Dec. 28, 1915. Proceedings of the National Academy of Sciences, vol. 2, No. 9, pp. 543-545; Sept., 1916. Bulletin of the American Mathematical Society, vol. 23, No. 4, pp. 166169; Jan., 1917.

Mitcheld, B. E. Complex conics and their real representation. Read Feb. 28, 1914. Author's dissertation. Lancaster, 1917. 4+45 pp.

Mitchell, H. H. On the congruence $c x^{\lambda}+1 \equiv d y^{\lambda}$ in a Galois field. Read Dec. 28, 1915. Annals of Mathematics, ser. 2, vol. 18, No. 3, pp. 120131; March, 1917. 
Moore, C. L. E. See Wilson, E. B.

Moore, C. N. On the developments in Bessel's functions. Read Jan. 1, 1916. Bulletin of the American Mathematical Society, vol. 23, No. 1, pp. 18-27; Oct., 1916.

Moore, R. L. A theorem concerning continuous curves. Read Oct. 28, 1916. Bulletin of the American Mathematical Society, vol. 23, No. 5, pp. 233-236; Feb., 1917.

Morgan, F. M. See Young, J. W.

Moritz, R. E. The cyclo-harmonograph. Read (San Francisco) May 22, 1914. Scientific American Supplement, vol. 82, No. 2118, pp. 84-85; August 5, 1916.

- On the construction of certain curves given in polar coordinates. Read (San Francisco) May 22, 1914. American Mathematical Monthly vol. 24, No. 5, pp. 213-220; May, 1917.

Morrison, F. M. On the relation between some important notions of projective and metrical differential geometry. Read (San Francisco) May 22, 1914. American Journal of Mathematics, vol. 39, No. 2, pp. 199-220; April, 1917.

Monse, H. C. M. Proof of a general theorem on the linear dependence of $p$ analytic functions of a single variable. Read Sept. 5, 1916 . Bulletin of the American Mathematical Society, vol. 23, No. 3, pp. 114-117; Dec., 1916.

Nelson, A. L. Plane nets with equal invariants. Read (Chicago) April 21, 1916. Rendiconti del Circolo Matematico di Palermo, vol. 41, Nos. 2-3, pp. 238-262; May-Dec., 1916.

OsGood, W. F. On infinite regions. Read Dec. 28, 1915. Transactions of the American Mathematical Society, vol. 17, No. 3, pp. 333-344; July, 1916.

Pfeiffer, G. A. Note on the linear dependence of analytic functions. Read Sept. 5, 1916. Bulletin of the American Mathematical Society, vol. 23, No. 3, pp. 117-118; Dec., 1916.

- On the conformal mapping of curvilinear angles. The functional equation $\phi[f(x)]=a_{1} \phi(x)$. Read Oct. 30, 1915 and April 29, 1916. Transactions of the American Mathematical Society, vol. 18, No. 2, pp. 185-198; April, 1917.

Pierce, T. A. The numerical factors of the arithmetic forms $\prod_{i=1}^{n}\left(1 \pm \alpha_{i}{ }^{m}\right)$. Read (San Francisco) Nov. 20, 1915. Annals of Mathematics, ser. 2, vol. 18, No. 2, pp. 53-64; Dec., 1916.

Porter, M. B. On Savary's construction for the centers of curvature of a roulette. Read (Southwestern Section) Nov. 27, 1915. American Mathematical Monthly, vol. 23, No. 7, pp. 238-240; Sept., 1916.

RIDER, P. R. A note on discontinuous solutions in the calculus of variations. Read April 25, 1914 and (Southwestern Section) Dec. 2, 1916. Bulletin of the American Mathematical Society, vol. 23, No. 5, pp. 237-240; Feb., 1917.

Riтt, J. F. On the derivatives of a function at a point. Read Feb. 27, 1915 and Dec. 27, 1915. Annals of Mathematics, ser. 2, vol. 18, No. 1, pp. 18-23; Sept., 1916.

- The resolution into partial fractions of the reciprocal of an entire function of genus zero. Read April 29, 1916. Transactions of the American Mathematical Society, vol. 18, No. 1, pp. 21-26; Jan., 1917. 
On a general class of linear homogeneous differential equations of infinite order with constant coefficients. Read April 29, 1916. Transactions of the American Mathematical Society, vol. 18, No. 1, pp. 27-49; Jan., 1917.

Robinson, L. B. A new canonical form for systems of partial differential equations. Read Feb. 22, 1913 and Dec. 30, 1913. American Journal of Mathematics, vol. 39, No. 1, pp. 95-112; Jan., 1917.

Roever, W. H. Graphical constructions for a function of a function and for a function given by a pair of parametric equations. Read (Southwestern Section) Nov. 27, 1915. American Mathematical Monthly, vol. 23, No. 9, pp. 330-333; Nov., 1916.

Rowe, J. E. The equation of a rational plane curve derived from its parametric equations (second paper). Read Feb. 24, 1917. Bulletin of the American Mathematical Society, vol. 23, No. 7, pp. 304-308; April, 1917. The projection of a line section upon the rational plane cubic curve. Read April 28, 1917. Bulletin of the American Mathematical Society, vol. 23, No. 9, pp. 405-407; June, 1917.

Running, T. R. New method of deriving weir formulas. Read (Chicago) April 21, 1916. Engineering News, vol. 76, No. 15, pp. 695-696; Oct. $12,1916$.

Silverman, L. L. On the notion of summability for the limit of a function of a continuous variable. Read Jan. 1, 1915. Transactions of the American Mathematical Society, vol. 17, No. 3, pp. 284-294; July, 1916.

- See Hurwitz, W. A.

Sisam, C. H. On sextic surfaces having a nodal curve of order 8 . Read (Southwestern Section) Nov. 27, 1915. American Journal of Mathematics, vol. 38, No. 4, pp. 373-386; Oct., 1916.

Smith, D. E. Mathematical problems in relation to the history of economics and commerce. Read Sept. 5, 1916. American Mathematical Monthly, vol. 24, No. 5, pp. 221-223; May, 1917.

Sмiтн, D. M. Jacobi's condition for the problem of Lagrange in the calculus of variations. Read (Chicago) April 21, 1916. Transactions of the American Mathematical Society, vol. 17, No. 4, pp. 459-475; Oct., 1916.

STAGER, H. W. A Sylow factor table of the first twelve thousand numbers. Read (San Francisco) Feb. 27, 1909 and (San Francisco) Oct. 28, 1911. Carnegie Institution Publication No. 151. Washington, 1916. 12+ $120 \mathrm{pp}$.

- Note on some applications of a geometrical transformation to certain systems of spheres. Read (San Francisco) April 12, 1913. American Mathematical Monthly, vol. 24, No. 4, pp. 154-162; April, 1917.

VANDIVER, H. S. Note on the distribution of quadratic residues. Read Oct. 30, 1915. Bulletin of the American Mathematical Society, vol. 23, No. 3, pp. 111-114; Dec., 1916.

_ Symmetric functions formed by systems of elements of a finite algebra and their connection with Fermat's quotient and Bernoulli's numbers. Read April 26, 1913 and Feb. 26, 1916. Annals of Mathematics, ser. 2, vol. 18, No. 3, pp. 105-114; March, 1917.

- The generalized Lagrange indeterminate congruence for a composite ideal modulus. Read Oct. 28, 1916. Annals of Mathematics, ser. 2, vol. 18, No. 3, pp. 115-119; March, 1917. 
WaHuIN, G. E. On the principal units of an algebraic domain $k(\mathfrak{p}, \alpha)$. Read (Chicago) April 10, 1914. Bulletin of the American Mathematical Society, vol. 23, No. 10, pp. 450-455; July, 1917.

Weaver, J. H. Pappus. Introductory paper. Read April 24, 1915. Bulletin of the American Mathematical Society, vol. 23, No. 3, pp. 127135; Dec., 1916.

Westfall, W. D. A. See Hedrick, E. R.

Whiтe, H. S. A variable system of sevens on two twisted cubic curves. Read Oct. 30, 1915. Proceedings of the National Academy of Sciences, vol. 2, No. 6, pp. 337-338; June, 1916.

- See Cole, F. N.

Wiener, N. Certain formal invariances in Boolean algebras. Read Dec. 27, 1916. Transactions of the American Mathematical Society, vol. 18, No. 1, pp. 65-72; Jan., 1917.

Wilson, E. B. and Moore, C. L. E. Differential geometry of two-dimensional surfaces in hyperspace. Read Dec. 27, 1915. Proceedings of the American Academy of Arts and Sciences, vol. 52, No. 6, pp. 267-368; Nov., 1916.

YeAton, C. H. Surfaces characterized by certain special properties of their directrix congruences. Read (Chicago) April 22, 1916. Annali di Matematica, ser. 3, vol. 26, No. 1, pp. 1-33; Dec., 1916.

Young, A. E. On the determination of a certain class of surfaces. Read Dec. 31, 1915. American Journal of Mathematics, vol. 39, No. 1, pp. 75-85; Jan., 1917.

Young, J. W. and Morgan, F. M. The geometries associated with a certain system of Cremona groups. Read April 26, 1913 and April 24, 1915. Transactions of the American Mathematical Society, vol. 17, No. 3, pp. 233-244; July, 1916. 